EISSN: 2706 -7947 ISSN: 2077- 4613

DOI: 10.36632/mejas/2021.11.1.15

Journal homepage: www.curresweb.com

Pages: 212-225

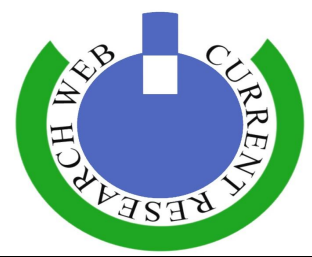

\title{
Effect of packaging types on prolonging marketing period and fruit quality of Balady lime (Citrus aurantifolia B.) fruits
}

\author{
Ahmed H. A. Mansour \\ Fruit Handling Department, Horticulture Research Institute, Agricultural Research Centre, (Affiliation \\ ID: 60019332), 9 Gamaa Street, 12619, Giza, Egypt.
}

Received: 12 December 2020 Accepted: 25 February 2021 Published: 01 March 2021

\begin{abstract}
The present study was conducted to investigate the influence of packaging types on prolonging the marketing period of Balady lime fruits as well as to maintain the best quality of fruits during the marketing periods. The fruits were harvested and received some post-harvest packaging treatments these treatments were packaging in perforated plastic bags (T1), Packaging in Perforated cellophane paper (T2), packaging in perforated plastic boxes (T3), packaging in non-perforated plastic bags contain calcium hydroxide (T4), packaging in non-perforated cellophane paper calcium hydroxide (T5), packaging in non-perforated plastic boxes calcium hydroxide (T6) and packaging in sealed foam plate by polyethylene stretch calcium hydroxide (T7). After packaging, fruits were stored in two different temperatures, room temperature $\left(25^{\circ} \mathrm{C}\right.$ and $50-65 \%$ relative humidity) and cold temperature $\left(7 \pm 2^{\circ} \mathrm{C}\right.$ and $65-75 \%$ relative humidity). Fruits kept at room temperature were examined every 2 days but, under cold temperature conditions, the samples were examined every 1 week. Our results demonstrated that these packagings reduce weight loss and unmarketable fruits weight as well as maintain the highest quality of fruits during marketing were packaging in non-perforated plastic bags (T4), packaging in non-perforated cellophane paper (T5), and packaging in non-perforated plastic boxes (T6).
\end{abstract}

Keywords: Packaging types, lime fruits, marketing, unmarketable, fruit quality

\section{Introduction}

Egyptian lime (Citrus aurantifolia B.) is one of the most popular fruit among citrus in Egypt. Egyptian lime reached 55797.47 feddan, represented about $10.3 \%$ of the total area of citrus (541723 feddan) and produced, 424204.1 ton represented about $10.35 \%$ of the total citrus production (4098590 tons) according to Ministry of Agriculture and Land Reclamation statistics (2015). No doubt that the process of handling and storage for the local or export market is important and of vital interest. In harvested fruits, loss in water vapour, results in shrinkage with peel, turgidity reduction, and lowered resistance to gas diffusion results in negative consequences with the taste and flavor (D'Aquino et al., 2001). Moreover, Panhwar (2006) reported that worldwide post-harvest losses in fruits are as high as $30-40$ percent and it seems to be more in some developing countries.

Shelf life is influenced by temperature, humidity, movement of air, the composition of gases, bruises, and microbial infection. Generally, the deterioration of citrus fruit during storage and shelf life is mainly affected by transpiration and respiration. Excessive weight loss due to transpiration can adversely affect the quality of fruit (Kawade and Albrigo, 1979)

Packaging of fruits decreased weight loss, decay and maintains fruits quality properties during storage and marketing (Faasema et al., 2011, Zagzog et al., 2012; Shaarawi et al., 2014; Mansour, 2015; Sohi et al., 2016; Bhattarai and Shah, 2017; Singh et al., 2018).

Corresponding Author Ahmed H. A. Mansour, Fruit Handling Department, Horticulture Research Institute, Agricultural Research Centre, (Affiliation ID: 60019332), 9 Gamaa Street, 12619, Giza, Egypt. E-mail: dr.mansour2015@yahoo.com 
In this context, the types of packaging have been reported to reduce the incidence of deterioration in fruits (Al-Hiti, 2005; Reddy et al., 2008; Faasema et al., 2011; Chaudhary et al., 2015; Dhillon et al., 2016). Also, benefits for eating quality of citrus were recorded using recommended number of microperforations per bag (Hussain et al., 2004).

The fruits of the municipal lemon appear mainly in the summer months, where temperatures reach their highest level, which negatively affects the period of marketing, handling, and quality of the fruits. Due to the high respiratory rate of fruits and the loss of water from them, this mainly affects the unmarketable fruits and their quality.

Therefore, the research aimed to choose the best type of packaging to prolong the marketing period as well as to maintain the quality of the Balady lime fruits during the marketing period.

\section{Materials and Methods}

The current study was carried out during 2018 and 2019 seasons. Balady lime fruits (Citrus aurantifolia B.) were purchased from a private orchard at Assiut Governorate, Egypt. Fruits were harvested at the green maturity stage from similar trees aged 10 years old grown in sandy soil irrigated through a drip irrigation system and planted $4 \times 4$ meters. The fruits were harvested and packed in plastic boxes and directly transferred to the laboratory of Assiut Agricultural Research Station. Fruits were washed, air-dried, and rechecked for any defects. The experimental design was conducted in a split-plot with three replicates, each replicate contained $300 \mathrm{~g}$ fruits approximately. The seven packaging pre-marketing applications were as follows:

T1 - Packaging in Perforated plastic bags (18 bores, 4 MM diameter).

T2 - Packaging in Perforated cellophane paper (18 bores, 4 MM diameter).

T3 - Packaging in Perforated plastic boxes (18 bores, 4 MM diameter).

T4 - Packaging in Non-perforated plastic bags, contains a bag with $25 \mathrm{~g}$ calcium hydroxide.

T5 - Packaging in Non-perforated cellophane paper, contains a bag with $25 \mathrm{~g}$ calcium hydroxide.

T6 - Packaging in Non-perforated plastic boxes, contains a bag with $25 \mathrm{~g}$ calcium hydroxide.

T7- Packaging in Sealed foam plate by polyethylene stretch, contains a bag with $25 \mathrm{~g}$ calcium hydroxide.

Fruits were stored in two different temperatures, room temperature $\left(25^{\circ} \mathrm{C}\right.$ and $50-65 \%$ relative humidity) and cold temperature $\left(7 \pm 2^{\circ} \mathrm{C}\right.$ and $65-75 \%$ relative humidity). Fruits kept at room temperature were examined every 2 days but, under cold temperature conditions, the samples were examined every 1 week to study the change in fruit characteristics during marketing periods.

\subsection{Measurements}

- Fruit weight loss $\%=$ (Initial Fruit weight- Final Fruit weight / Initial Fruit weight) $x 100$

- Fruit unmarketable \% $=($ Weight of unmarketable Fruit / Initial Fruit weight $) \times 100$

- Juice weight $\%=($ Juice weight / fruit weight $) \times 100$

- Total soluble solids (TSS \%) were determined using a hand refractometer.

- Titratable acidity: Acidity of the fruit juice was determined by titration of $5 \mathrm{ml}$ juice against $0.3 \mathrm{~N}$ sodium hydroxide using phenolphthaline as an indicator. Titratable acidity was expressed as grams of citric acid per $100 \mathrm{ml}$ fruit juice according to the A.O.A.C. (1985).

- Ascorbic acid (V.C.) content: The vitamin "C" content was determined, in fruit juice during cold storage titration with, 2,6 -Dichlorophenol indophenol blue dye. According to the A.O.A.C. (1985), and expressed as milligrams of ascorbic acid/100 $\mathrm{g}$ juice.

\subsection{Statistical analysis}

This experiment was conducted in a split-plot design with three replicates which marketing periods at the main plot and treatments of Packaging in a subplot. The data was Statistically analyzed by Statistix 8.1 software (Analytical Software, 2005), according to Snedecor and Cochran (1990) using L.S.D. at the level of 0.05 . 


\section{Results}

\subsection{The percentage of fruit weight loss}

\subsubsection{During cold marketing}

Data presented in Table (1) clear that fruit weight loss percentage were increased with advancing cold marketing period. No loss in fruit weight was reported for one week in packed fruits in nonperforated plastic bags (T4) or non-perforated cellophane paper (T5) or non-perforated plastic boxes (T6) during 2019 season. The lowest values in this respect were noticed in fruits packed in nonperforated plastic bags (T4) or non-perforated cellophane paper (T5) or non-perforated plastic boxes (T6). On the other hand, the highest values in this respect were noticed in fruits packed in Perforated plastic bags (T1) or Perforated cellophane paper (T2), or perforated plastic boxes (T3) during both seasons.

The interaction between the cold marketing period and packaging treatments was significant in the two seasons respecting. Prolonging the cold marketing period increased fruit weight loss $\%$ under the same treatment. While the highest values of fruit weight loss \% came from the interaction between the marketing period (after 5 weeks) during both seasons.

Table 1: The effect of some types of packaging on weight loss \% of Balady lime fruits during cold marketing in 2018 and 2019 seasons.

\begin{tabular}{|c|c|c|c|c|c|c|c|}
\hline \multirow{2}{*}{$\begin{array}{c}\text { Treatments } \\
\text { (T) }\end{array}$} & \multicolumn{7}{|c|}{ Marketing periods (P) } \\
\hline & 0 week & 1 week & 2 week & 3 week & 4 week & 5 week & Mean \\
\hline \multicolumn{8}{|c|}{2018} \\
\hline$T_{1}$ & 0.00 & 5.18 & 9.55 & 13.89 & 18.55 & 22.52 & 11.62 \\
\hline $\mathbf{T}_{2}$ & 0.00 & 5.00 & 9.57 & 14.28 & 18.28 & 21.74 & 11.48 \\
\hline $\mathbf{T}_{3}$ & 0.00 & 4.96 & 10.17 & 14.40 & 18.89 & 21.89 & 11.72 \\
\hline $\mathbf{T}_{4}$ & 0.00 & 0.25 & 0.72 & 1.24 & 1.66 & 2.49 & 1.06 \\
\hline $\mathbf{T}_{5}$ & 0.00 & 0.20 & 0.57 & 1.26 & 1.39 & 2.70 & 1.02 \\
\hline$T_{6}$ & 0.00 & 0.18 & 0.80 & 1.28 & 1.74 & 2.20 & 1.03 \\
\hline $\mathbf{T}_{7}$ & 0.00 & 2.34 & 4.82 & 7.65 & 9.91 & 13.75 & 6.41 \\
\hline Mean & 0.00 & 2.59 & 5.17 & 7.71 & 10.06 & 12.47 & \\
\hline L.S.D. 0.05 : & (P): 0.32 & $(\mathrm{~T}): 0.67$ & (PxT & & & & \\
\hline \multicolumn{8}{|c|}{2019} \\
\hline $\mathbf{T}_{1}$ & 0.00 & 4.29 & 9.55 & 14.65 & 17.51 & 21.09 & 11.18 \\
\hline $\mathbf{T}_{2}$ & 0.00 & 4.54 & 11.15 & 14.17 & 18.08 & 20.30 & 11.37 \\
\hline $\mathbf{T}_{3}$ & 0.00 & 4.51 & 9.72 & 14.95 & 17.10 & 19.43 & 10.95 \\
\hline $\mathbf{T}_{4}$ & 0.00 & 0.00 & 0.71 & 1.23 & 1.68 & 2.13 & 0.96 \\
\hline$T_{5}$ & 0.00 & 0.00 & 0.48 & 1.21 & 2.04 & 2.59 & 1.05 \\
\hline$T_{6}$ & 0.00 & 0.00 & 0.67 & 1.18 & 1.56 & 1.94 & 0.89 \\
\hline $\mathbf{T}_{7}$ & 0.00 & 2.55 & 3.97 & 5.15 & 7.62 & 11.59 & 5.15 \\
\hline Mean & 0.00 & 2.27 & 5.18 & 7.51 & 9.37 & 11.30 & \\
\hline
\end{tabular}

L.S.D. 0.05 :

(P):0.50

(T): 0.87

(PxT): 2.14

T1 Perforated plastic bags

$\mathbf{T}_{\mathbf{2}} \quad$ Perforated cellophane paper

$\mathbf{T}_{3} \quad$ Perforated plastic boxes

$\mathbf{T}_{4} \quad$ Non-perforated plastic bags
T5 Non-perforated cellophane paper

T6 Non-perforated plastic boxes

$\mathbf{T}_{7}$ Sealed foam plate by polye. stretch

\subsubsection{During marketing at room temperature}

Data illustrated in Table (2) reveal that fruit weight loss percentages were increased with advancing marketing periods at room temperature. Packaging in Perforated plastic bags (T1), Perforated cellophane paper (T2), and perforated plastic boxes (T3) recorded the highest values of weight loss percentage without significant differences Between them during marketing at room temperature in both seasons. While, packaging in non-perforated plastic boxes (T6), recorded the least without significant differences with non-perforated cellophane paper (T5) in the first season. For the second season, the least values in this respect were noticed in (T4), (T6), and (T5), there was a non-significant difference between them. 
The interaction between marketing at room temperature period and packaging treatments was significant in the two seasons respecting. Prolonging the marketing period increased fruit weight loss $\%$ under the same treatment. However, the lowest values of fruit weight loss $\%$ came from the interaction between the marketing period (after 8 days) with non-perforated plastic boxes $(1.11 \%$ and $3.93 \%$ during 2018 and 2019 seasons, respectively).

Table 2: The effect of some types of packaging on weight loss \% of Balady lime fruits during marketing at room temperature.in 2018 and 2019 seasons.

\begin{tabular}{|c|c|c|c|c|c|c|}
\hline \multirow{2}{*}{$\begin{array}{l}\text { Treatments } \\
\text { (T) }\end{array}$} & \multicolumn{6}{|c|}{ Marketing periods (P) } \\
\hline & O days & 2 days & 4 days & 6 days & 8 days & Mean \\
\hline \multicolumn{7}{|c|}{2018} \\
\hline $\mathbf{T}_{1}$ & 0.00 & 4.70 & 9.71 & 15.43 & 21.32 & 10.23 \\
\hline $\mathbf{T}_{2}$ & 0.00 & 3.71 & 8.40 & 16.77 & 20.02 & 9.78 \\
\hline $\mathbf{T}_{3}$ & 0.00 & 4.02 & 9.95 & 15.90 & 20.33 & 10.04 \\
\hline $\mathbf{T}_{4}$ & 0.00 & 0.74 & 1.31 & 2.95 & 3.16 & 1.63 \\
\hline$T_{5}$ & 0.00 & 0.36 & 0.80 & 1.78 & 2.06 & 1.00 \\
\hline$T_{6}$ & 0.00 & 0.18 & 0.31 & 0.92 & 1.11 & 0.50 \\
\hline $\mathbf{T}_{7}$ & 0.00 & 2.17 & 4.80 & 7.56 & 10.13 & 4.93 \\
\hline Mean & 0.00 & 2.27 & 5.04 & 8.76 & 11.16 & \\
\hline \multirow{2}{*}{\multicolumn{7}{|c|}{$(\mathrm{Px} 1): 1.66$}} \\
\hline & & & & & & \\
\hline $\mathbf{T}_{1}$ & 0.00 & 4.01 & 9.12 & 14.60 & 18.21 & 9.19 \\
\hline $\mathbf{T}_{2}$ & 0.00 & 4.21 & 9.58 & 14.18 & 17.21 & 9.04 \\
\hline $\mathbf{T}_{3}$ & 0.00 & 5.02 & 8.88 & 13.67 & 18.65 & 9.24 \\
\hline $\mathbf{T}_{4}$ & 0.00 & 1.21 & 1.75 & 2.95 & 4.01 & 1.98 \\
\hline$T_{5}$ & 0.00 & 0.41 & 1.65 & 2.67 & 4.07 & 1.76 \\
\hline$T_{6}$ & 0.00 & 1.13 & 1.50 & 2.63 & 3.93 & 1.84 \\
\hline $\mathbf{T}_{7}$ & 0.00 & 2.05 & 4.10 & 7.48 & 9.33 & 4.59 \\
\hline Mean & 0.00 & 2.58 & 5.23 & 8.31 & 10.77 & \\
\hline L.S.D. 0.05 & $(\mathrm{P}): 0.61$ & & & )$: 1.58$ & & \\
\hline
\end{tabular}

$\mathbf{T}_{1} \quad$ Perforated plastic bags

$\mathbf{T}_{2} \quad$ Perforated cellophane paper

$\mathbf{T}_{\mathbf{3}} \quad$ Perforated plastic boxes

$\mathbf{T}_{4} \quad$ Non-perforated plastic bags
T5 $_{5}$ Non-perforated cellophane paper

$\mathbf{T}_{6} \quad$ Non-perforated plastic boxes

$\mathbf{T}_{7} \quad$ Sealed foam plate by polye. stretch

\subsection{The percentage of unmarketable fruits}

\subsubsection{During cold marketing}

Data presented in Table (3) demonstrate that unmarketable fruits Percentage was increased with increasing cold marketable periods. Data also clear that No fruits were unmarketable after 1 week of cold marketing in all treatments during both seasons. No values were recorded for unmarketable fruits after one week in cold marketing, and then they were steadily increased with the advance in the marketable period to reach the uppermost values at the end of the marketing period. Moreover, there were no unmarketable fruits during the study period (4 weeks) of cold marketing when packaged in non-perforated cellophane paper (T5) or non-perforated plastic boxes (T6). Also, there are no significant differences between (T5) and (T6) in both seasons of study.

The interaction between marketing periods at cold marketing and packaging treatments was significant in both seasons respecting. Also, the highest percentage of unmarketable fruits came from the interaction between the marketing period (after 5 weeks) with perforated cellophane paper $(35.88 \%$ and $40.05 \%$ in $1^{\text {st }}$ and $2^{\text {nd }}$ seasons, respectively).

\subsubsection{During marketing at room temperature}

Data are shown in Table (4) clear that unmarketable fruits Percentage were increased with increasing marketing periods at room temperature. All packages did not contain any unmarketable fruits for 2 days in both seasons. Moreover, packages in non-perforated plastic bags or non-perforated cellophane paper or non-perforated plastic boxes did not contain any unmarketable fruits for 6 days in both seasons. 
Packaging in perforated plastic bags (T1) gave the highest percentage of unmarketable fruits $(13.36 \%$ and $11.57 \%$ in first and second seasons, respectively), however, non-perforated cellophane paper (T5) gave the lowest percentage of unmarketable fruits $(0.56 \%$ and 0.36 in 2018 and 2019 seasons, respectively), it is also no significant differences between (T5), (T6), and (T4).

Table 3: The effect of some types of packaging on un-marketable \% of Balady lime fruits during cold marketing in 2018 and 2019 seasons.

\begin{tabular}{|c|c|c|c|c|c|c|c|}
\hline \multirow{2}{*}{$\begin{array}{l}\text { Treatments } \\
\text { (T) }\end{array}$} & \multicolumn{7}{|c|}{ Marketing periods (P) } \\
\hline & 0 week & 1 week & 2 week & 3 week & 4 week & 5 week & Mean \\
\hline \multicolumn{8}{|c|}{2018} \\
\hline$T_{1}$ & 0.00 & 0.00 & 10.63 & 18.56 & 20.63 & 34.62 & 14.07 \\
\hline $\mathbf{T}_{2}$ & 0.00 & 0.00 & 0.00 & 15.39 & 25.39 & 35.88 & 12.78 \\
\hline $\mathbf{T}_{3}$ & 0.00 & 0.00 & 8.42 & 9.42 & 17.55 & 32.31 & 11.28 \\
\hline $\mathbf{T}_{4}$ & 0.00 & 0.00 & 0.00 & 3.35 & 5.29 & 10.16 & 3.13 \\
\hline$T_{5}$ & 0.00 & 0.00 & 0.00 & 0.00 & 0.00 & 13.29 & 2.22 \\
\hline$T_{6}$ & 0.00 & 0.00 & 0.00 & 0.00 & 0.00 & 12.40 & 2.07 \\
\hline $\mathbf{T}_{7}$ & 0.00 & 0.00 & 0.00 & 0.00 & 10.40 & 24.23 & 5.77 \\
\hline Mean & 0.00 & 0.00 & 2.72 & 6.67 & 11.32 & 23.27 & \\
\hline \multirow{2}{*}{\multicolumn{8}{|c|}{$\begin{array}{l}\text { (PxT): } 1.51 \\
2019\end{array}$}} \\
\hline & & & & & & & \\
\hline$T_{1}$ & 0.00 & 0.00 & 0.00 & 15.42 & 20.10 & 38.34 & 12.31 \\
\hline $\mathbf{T}_{2}$ & 0.00 & 0.00 & 0.00 & 18.56 & 18.56 & 40.05 & 12.86 \\
\hline $\mathbf{T}_{3}$ & 0.00 & 0.00 & 9.70 & 13.29 & 15.42 & 35.98 & 12.40 \\
\hline $\mathbf{T}_{4}$ & 0.00 & 0.00 & 0.00 & 0.00 & 3.35 & 5.24 & 1.43 \\
\hline $\mathbf{T}_{5}$ & 0.00 & 0.00 & 0.00 & 0.00 & 0.00 & 3.71 & 0.62 \\
\hline$T_{6}$ & 0.00 & 0.00 & 0.00 & 0.00 & 0.00 & 4.10 & 0.68 \\
\hline $\mathbf{T}_{7}$ & 0.00 & 0.00 & 0.00 & 0.00 & 5.80 & 20.98 & 4.46 \\
\hline Mean & 0.00 & 0.00 & 1.39 & 6.75 & 9.03 & 21.20 & \\
\hline L.S.D. 0.05 & (P): 0.85 & (T): 0.52 & (PxT): & & & & \\
\hline
\end{tabular}

Table 4: The effect of some types of packaging on un-marketable \% of Balady lime fruits during marketing at room temperature.in 2018 and 2019 seasons.

\begin{tabular}{|c|c|c|c|c|c|c|}
\hline \multirow{2}{*}{$\begin{array}{l}\text { Treatments } \\
\text { (T) }\end{array}$} & \multicolumn{6}{|c|}{ Marketing periods (P) } \\
\hline & 0 days & 2 days & 4 days & 6 days & 8 days & Mean \\
\hline \multicolumn{7}{|c|}{2018} \\
\hline$T_{1}$ & 0.00 & 0.00 & 1.85 & 20.88 & 44.06 & 13.36 \\
\hline $\mathbf{T}_{2}$ & 0.00 & 0.00 & 3.38 & 18.31 & 42.58 & 12.85 \\
\hline $\mathbf{T}_{3}$ & 0.00 & 0.00 & 0.00 & 21.66 & 39.52 & 12.24 \\
\hline $\mathbf{T}_{4}$ & 0.00 & 0.00 & 0.00 & 0.00 & 7.39 & 1.48 \\
\hline$T_{5}$ & 0.00 & 0.00 & 0.00 & 0.00 & 2.78 & 0.56 \\
\hline$T_{6}$ & 0.00 & 0.00 & 0.00 & 0.00 & 4.34 & 0.87 \\
\hline $\mathbf{T}_{7}$ & 0.00 & 0.00 & 0.00 & 9.28 & 24.55 & 6.77 \\
\hline Mean & 0.00 & 0.00 & 0.75 & 11.45 & 26.46 & \\
\hline \multirow{2}{*}{\multicolumn{7}{|c|}{$(\mathrm{Px} 1): 1.12$}} \\
\hline & & & & & & \\
\hline$T_{1}$ & 0.00 & 0.00 & 1.56 & 14.06 & 42.22 & 11.57 \\
\hline $\mathbf{T}_{2}$ & 0.00 & 0.00 & 2.99 & 14.35 & 39.46 & 11.36 \\
\hline$T_{3}$ & 0.00 & 0.00 & 0.00 & 14.52 & 40.97 & 11.10 \\
\hline$T_{4}$ & 0.00 & 0.00 & 0.00 & 0.00 & 3.69 & 0.74 \\
\hline$T_{5}$ & 0.00 & 0.00 & 0.00 & 0.00 & 1.79 & 0.36 \\
\hline$T_{6}$ & 0.00 & 0.00 & 0.00 & 0.00 & 2.71 & 0.54 \\
\hline $\mathbf{T}_{7}$ & 0.00 & 0.00 & 0.00 & 5.45 & 19.13 & 4.92 \\
\hline Mean & 0.00 & 0.00 & 0.65 & 6.91 & 21.42 & \\
\hline L.S.D. 0.05 & $(\mathrm{P}): 0.34$ & (T): 0.4 & & .06 & & \\
\hline
\end{tabular}

$\mathbf{T}_{1} \quad$ Perforated plastic bags

$\mathbf{T}_{2} \quad$ Perforated cellophane paper

$\mathbf{T}_{\mathbf{3}} \quad$ Perforated plastic boxes

$\mathbf{T}_{4} \quad$ Non-perforated plastic bags
$\mathbf{T}_{5} \quad$ Non-perforated cellophane paper

$\mathbf{T}_{6}$ Non-perforated plastic boxes

$\mathbf{T}_{7}$ Sealed foam plate by polye. stretch 
The interaction between marketing at room temperature period and packaging treatments was significant in the two seasons respecting. The highest percentage of unmarketable fruits recorded after 8 days in both seasons in perforated plastic bags $\left(44.06 \%\right.$ and $42.22 \%$ during $1^{\text {st }}$ and $2^{\text {nd }}$ seasons, respectively).

\subsection{Fruit juice percentage}

\subsubsection{During cold marketing}

Data in table (5) clear that the juice percentage of lime fruits was decreased with the increase of cold marketing periods in both seasons. The lowest values of Juice were recorded after 5 weeks of cold marketing periods (43.27\% and $42.70 \%$ in 2018 and 2019, respectively). Packaging treatments affected juice $\%$ during cold marketing in both seasons. The lowest values of juice $\%$ were obtained from T1, T2, and T3 without significant difference. However, T4, T5, T6, and T7 treatments recorded the highest values of juice $\%$ without significant difference.

The interaction between the cold marketing period and packaging treatments recorded significant effects with juice $\%$ in both seasons.

Table 5: The effect of some types of packaging on juice weight $\%$ of Balady lime fruits during cold marketing.in 2018 and 2019 seasons.

\begin{tabular}{|c|c|c|c|c|c|c|c|}
\hline \multirow{2}{*}{$\begin{array}{l}\text { Treatments } \\
\text { (T) }\end{array}$} & \multicolumn{7}{|c|}{ Marketing periods (P) } \\
\hline & 0 week & 1 week & 2 week & 3 week & 4 week & 5 week & Mean \\
\hline \multicolumn{8}{|c|}{2018} \\
\hline$T_{1}$ & 46.02 & 45.24 & 43.70 & 43.66 & 43.35 & 42.19 & 44.03 \\
\hline $\mathbf{T}_{2}$ & 46.02 & 45.69 & 44.84 & 43.48 & 42.81 & 42.06 & 44.15 \\
\hline $\mathbf{T}_{3}$ & 46.02 & 45.31 & 44.21 & 43.55 & 42.66 & 41.29 & 43.84 \\
\hline $\mathbf{T}_{4}$ & 46.02 & 46.01 & 45.71 & 45.19 & 44.99 & 44.48 & 45.40 \\
\hline $\mathbf{T}_{5}$ & 46.02 & 46.00 & 45.86 & 45.58 & 45.46 & 44.66 & 45.60 \\
\hline$T_{6}$ & 46.02 & 46.00 & 45.93 & 45.39 & 44.99 & 44.36 & 45.45 \\
\hline $\mathbf{T}_{7}$ & 46.02 & 45.69 & 45.60 & 45.51 & 44.76 & 43.83 & 45.24 \\
\hline Mean & 46.02 & 45.71 & 45.12 & 44.62 & 44.15 & 43.27 & \\
\hline L.S.D. 0.05 & (P): 1.17 & $(T): 0.63$ & (PxT) & 1.54 & & & \\
\hline \multicolumn{8}{|c|}{2019} \\
\hline$T_{1}$ & 44.95 & 44.45 & 43.66 & 42.66 & 41.77 & 40.53 & 43.00 \\
\hline $\mathbf{T}_{2}$ & 44.95 & 44.35 & 44.31 & 43.36 & 42.56 & 41.81 & 43.56 \\
\hline$T_{3}$ & 44.95 & 44.44 & 44.29 & 43.66 & 43.13 & 42.62 & 43.85 \\
\hline $\mathbf{T}_{4}$ & 44.95 & 44.94 & 44.82 & 44.50 & 44.35 & 43.73 & 44.55 \\
\hline$T_{5}$ & 44.95 & 44.91 & 44.80 & 44.32 & 43.68 & 43.44 & 44.35 \\
\hline$T_{6}$ & 44.95 & 44.90 & 44.27 & 44.23 & 43.92 & 43.76 & 44.34 \\
\hline $\mathbf{T}_{7}$ & 44.95 & 44.55 & 44.12 & 43.31 & 43.24 & 43.02 & 43.87 \\
\hline Mean & 44.95 & 44.65 & 44.32 & 43.72 & 43.24 & 42.70 & \\
\hline L.S.D. 0.05 & (P): 1.64 & (T): 0.64 & $(\mathrm{Pr}$ & ): 1.56 & & & \\
\hline
\end{tabular}

\subsubsection{During marketing at room temperature}

Juice $\%$ during marketing at room temperature exhibited a similar trend to Juice $\%$ during cold marketing as demonstrated in the table (6). Increasing marketing period at room temperature caused a decrease in juice $\%$. The lowest values of juice were recorded after 8 days of marketing at room temperature $\left(42.36 \%\right.$ and 41.99 during $1^{\text {st }}$ and $2^{\text {nd }}$ seasons, respectively). The maximum values were obtained from $\mathrm{T} 1, \mathrm{~T} 2$, and $\mathrm{T} 3$ in both seasons. While, $\mathrm{T} 5$ treatment recorded the highest value of juice $\%$ (44.97\% and 44.12\% in 2018 and 2019, respectively. This was not significantly differing from T4, T6 and T7.

The interaction between the marketing period and packaging treatments recorded significant effects with juice \% during marketing at room temperature in the two seasons. Packed fruits in the perforated plastic bags or perforated plastic boxes recorded the least values without significant differences between them after 8 days in the first season, while, packed fruits in the perforated cellophane paper recorded the lowest value after 8 days in the second season. 
Table 6: The effect of some types of packaging on juice weight \% of Balady lime fruits during marketing at room temperature.in 2018 and 2019 seasons.

\begin{tabular}{|c|c|c|c|c|c|c|}
\hline \multirow{2}{*}{$\begin{array}{l}\text { Treatments } \\
\text { (T) }\end{array}$} & \multicolumn{6}{|c|}{ Marketing periods (P) } \\
\hline & 0 days & 2 days & 4 days & 6 days & 8 days & Mean \\
\hline \multicolumn{7}{|c|}{2018} \\
\hline $\mathbf{T}_{1}$ & 46.02 & 45.14 & 44.44 & 42.86 & 40.66 & 43.82 \\
\hline $\mathbf{T}_{2}$ & 46.02 & 44.64 & 43.69 & 43.48 & 41.99 & 43.96 \\
\hline $\mathbf{T}_{3}$ & 46.02 & 45.13 & 44.23 & 42.36 & 41.44 & 43.84 \\
\hline $\mathbf{T}_{4}$ & 46.02 & 45.93 & 44.94 & 43.84 & 43.01 & 44.75 \\
\hline $\mathbf{T}_{\mathbf{5}}$ & 46.02 & 45.84 & 44.88 & 44.12 & 44.00 & 44.97 \\
\hline $\mathbf{T}_{6}$ & 46.02 & 45.33 & 43.89 & 44.02 & 43.08 & 44.47 \\
\hline $\mathbf{T}_{7}$ & 46.02 & 45.63 & 45.57 & 44.13 & 42.33 & 44.74 \\
\hline Mean & 46.02 & 45.38 & 44.52 & 43.54 & 42.36 & \\
\hline L.S.D. 0.05 & $(\mathrm{P}): 0.91$ & $(\mathrm{~T}): 0.52$ & & & & \\
\hline \multicolumn{7}{|c|}{$($ PxT): 1.17} \\
\hline $\mathbf{T}_{1}$ & 44.95 & 43.89 & 42.56 & 42.32 & 41.44 & 43.03 \\
\hline $\mathbf{T}_{2}$ & 44.95 & 43.87 & 43.39 & 42.67 & 40.13 & 43.00 \\
\hline $\mathbf{T}_{3}$ & 44.95 & 42.78 & 42.62 & 42.45 & 41.95 & 42.95 \\
\hline $\mathbf{T}_{4}$ & 44.95 & 44.39 & 43.99 & 43.11 & 42.65 & 43.82 \\
\hline$T_{5}$ & 44.95 & 44.35 & 44.00 & 44.00 & 43.28 & 44.12 \\
\hline $\mathbf{T}_{6}$ & 44.95 & 44.53 & 44.05 & 43.13 & 42.25 & 43.78 \\
\hline $\mathbf{T}_{7}$ & 44.95 & 44.83 & 43.26 & 42.54 & 42.22 & 43.56 \\
\hline Mean & 44.95 & 44.09 & 43.41 & 42.89 & 41.99 & \\
\hline L.S.D. 0.05 & $(\mathrm{P}): 1.70$ & (T): & & 23 & & \\
\hline
\end{tabular}

\subsection{Total soluble solids percentage (TSS \%)}

\subsubsection{During cold marketing}

Data presented in Table 7 reveal that TSS \% was gradually increased with the advancing cold marketing period in both seasons. TSS was significantly affected by the tested packaging treatments in both seasons. The highest values of TSS \% were recorded in fruits packed in Perforated plastic bags (7.61 and $7.62 \%$ in the two seasons, respectively); while the least values were recorded in fruits packed in non-perforated plastic bags ( 7.10 and $6.88 \%$ in the two seasons, respectively).

Table 7: The effect of some types of packaging on total soluble solids percentage (TSS\%) of Balady lime fruits during cold marketing.in 2018 and 2019 seasons.

\begin{tabular}{|c|c|c|c|c|c|c|c|}
\hline \multirow{2}{*}{$\begin{array}{l}\text { Treatments } \\
\text { (T) }\end{array}$} & \multicolumn{7}{|c|}{ Marketing periods (P) } \\
\hline & O week & 1 week & 2 week & 3 week & 4 week & 5 week & Mean \\
\hline & & & 2018 & & & & \\
\hline $\mathbf{T}_{1}$ & 6.93 & 7.20 & 7.47 & 7.57 & 8.00 & 8.47 & 7.61 \\
\hline $\mathbf{T}_{2}$ & 6.93 & 7.10 & 7.23 & 7.33 & 7.70 & 8.37 & 7.44 \\
\hline $\mathbf{T}_{3}$ & 6.93 & 7.17 & 7.23 & 7.33 & 7.93 & 8.27 & 7.48 \\
\hline $\mathbf{T}_{4}$ & 6.93 & 6.97 & 7.00 & 7.10 & 7.20 & 7.40 & 7.10 \\
\hline $\mathbf{T}_{5}$ & 6.93 & 7.07 & 7.10 & 7.13 & 7.70 & 7.97 & 7.32 \\
\hline$T_{6}$ & 6.93 & 7.00 & 7.13 & 7.30 & 7.63 & 7.87 & 7.31 \\
\hline $\mathbf{T}_{7}$ & 6.93 & 7.10 & 7.20 & 7.40 & 7.80 & 8.00 & 7.41 \\
\hline Mean & 6.93 & 7.09 & 7.19 & 7.31 & 7.71 & 8.05 & \\
\hline L.S.D. 0.05 & (P): 0.20 & & & (PxT): 0 & & & \\
\hline \multicolumn{8}{|c|}{2019} \\
\hline$T_{1}$ & 6.80 & 7.20 & 7.40 & 7.80 & 8.03 & 8.47 & 7.62 \\
\hline $\mathbf{T}_{2}$ & 6.80 & 7.00 & 7.33 & 7.47 & 7.87 & 8.50 & 7.50 \\
\hline $\mathbf{T}_{3}$ & 6.80 & 7.00 & 7.20 & 7.70 & 8.10 & 8.50 & 7.55 \\
\hline $\mathbf{T}_{4}$ & 6.80 & 6.80 & 6.86 & 6.90 & 6.93 & 7.00 & 6.88 \\
\hline $\mathbf{T}_{5}$ & 6.80 & 6.86 & 6.97 & 7.23 & 7.80 & 8.10 & 7.29 \\
\hline$T_{6}$ & 6.80 & 6.83 & 6.93 & 7.00 & 7.60 & 7.80 & 7.16 \\
\hline $\mathbf{T}_{7}$ & 6.80 & 7.10 & 7.30 & 7.40 & 7.80 & 8.10 & 7.42 \\
\hline Mean & 6.80 & 6.97 & 7.14 & 7.36 & 7.73 & 8.07 & \\
\hline L.S.D. 0.05 & (P): 0.17 & $(\mathrm{~T})$ : & & 0.27 & & & \\
\hline
\end{tabular}


The interaction between the cold marketing period and packaging treatments recorded significant effects with juice TSS \% during cold marketing in the two seasons. The highest TSS \%was after 5 weeks of cold marketing in all types of packages.

\subsubsection{During marketing at room temperature}

From Table (8), it is clear that TSS \% were increased with the advance of marketing at room temperature period to reach uppermost values after 8 days in both studied seasons. Packaging treatments had significant effects on juice \% during marketing at room temperature in both seasons. The highest values of TSS \% were recorded in fruits packed in Perforated plastic bags treatment (8.04 and 7.63\% in the two seasons, respectively). While, the least values were recorded in fruits packed in nonperforated plastic boxes (T6) (7.46 and 7.14\% in the two seasons, respectively).

The interaction between the marketing period and packaging treatments recorded significant effects with TSS \% during marketing at room temperature in the two seasons.

Table 8: The effect of some types of packing on total soluble solids percentage (TSS\%) of Balady lime fruits during marketing at room temperature.in 2018 and 2019 seasons.

\begin{tabular}{|c|c|c|c|c|c|c|}
\hline \multirow{2}{*}{$\begin{array}{l}\text { Treatments } \\
\text { (T) }\end{array}$} & \multicolumn{6}{|c|}{ Marketing periods (P) } \\
\hline & 0 days & 2 days & 4 days & 6 days & 8 days & Mean \\
\hline \multicolumn{7}{|c|}{2018} \\
\hline $\mathbf{T}_{1}$ & 6.93 & 7.73 & 8.13 & 8.67 & 8.73 & 8.04 \\
\hline $\mathbf{T}_{2}$ & 6.93 & 7.83 & 8.00 & 8.33 & 8.77 & 7.97 \\
\hline$T_{3}$ & 6.93 & 7.67 & 7.87 & 8.27 & 8.80 & 7.91 \\
\hline $\mathbf{T}_{4}$ & 6.93 & 7.50 & 7.77 & 8.10 & 8.13 & 7.69 \\
\hline $\mathbf{T}_{5}$ & 6.93 & 7.33 & 7.73 & 7.83 & 8.03 & 7.57 \\
\hline$T_{6}$ & 6.93 & 7.23 & 7.47 & 7.80 & 7.87 & 7.46 \\
\hline $\mathbf{T}_{7}$ & 6.93 & 7.60 & 7.67 & 8.27 & 8.30 & 7.75 \\
\hline Mean & 6.93 & 7.56 & 7.81 & 8.18 & 8.38 & \\
\hline L.S.D. 0.05 & $(\mathrm{P}): 0.29$ & (T): 0 & & 0.42 & & \\
\hline \multicolumn{7}{|c|}{2019} \\
\hline$T_{1}$ & 6.80 & 7.30 & 7.90 & 8.00 & 8.13 & 7.63 \\
\hline $\mathbf{T}_{2}$ & 6.80 & 7.10 & 7.30 & 7.60 & 7.80 & 7.32 \\
\hline$T_{3}$ & 6.80 & 7.00 & 7.20 & 7.80 & 7.83 & 7.33 \\
\hline $\mathbf{T}_{4}$ & 6.80 & 7.13 & 7.33 & 7.37 & 7.60 & 7.25 \\
\hline$T_{5}$ & 6.80 & 6.97 & 7.27 & 7.50 & 7.57 & 7.22 \\
\hline$T_{6}$ & 6.80 & 7.07 & 7.13 & 7.20 & 7.50 & 7.14 \\
\hline $\mathbf{T}_{7}$ & 6.80 & 7.00 & 7.20 & 7.50 & 7.86 & 7.27 \\
\hline Mean & 6.80 & 7.08 & 7.33 & 7.57 & 7.76 & \\
\hline
\end{tabular}

\subsection{Titratable acidity percentage (TA\%)}

\subsubsection{During cold marketing}

Data presented in table (9) demonstrate that juice acidity \% was gradually and significantly decreased with the advancing marketing period in the two seasons. The lowest value (5.38 and $5.75 \%$ ) were recorded after 5 weeks in both seasons. The lowest percentage of acidity was recorded in the packed fruits in perforated plastic bags (5.82\% and 5.93\% in 2018 and 2019, respectively). While the highest was recorded in the packed fruits in non-perforated cellophane paper $(6.25 \%$ and $6.41 \%$ during first and second seasons, respectively) in two seasons.

The interaction between the cold marketing period and packaging treatments had significant effects with juice acidity $\%$ in the two seasons.

\subsubsection{During marketing at room temperature}

Data illustrated in Table (10) shows a significant effect of the marketing period on juice acidity $\%$ during marketing at room temperature in both seasons. Packaging in non-perforated cellophane paper (T5) recorded the highest juice acidity $\%$ (5.94\% and 6.15\% during $1^{\text {st }}$ and $2^{\text {nd }}$ seasons, respectively) without significant differences with non-perforated plastic bags (T4) during marketing at room temperature in both seasons. 
The interaction between the marketing period and packaging treatments had significant effects on juice acidity $\%$ in both seasons during marketing at room temperature.

Table 9: The effect of some types of packaging on titratable acidity percentage (TA) (as grams of citric acid/100 ml juice) of Balady lime fruits during cold marketing in 2018 and 2019 seasons.

\begin{tabular}{|c|c|c|c|c|c|c|c|}
\hline \multirow{2}{*}{$\begin{array}{l}\text { Treatments } \\
\text { (T) }\end{array}$} & \multicolumn{7}{|c|}{ Marketing periods (P) } \\
\hline & 0 week & 1 week & 2 week & 3 week & 4 week & 5 week & Mean \\
\hline \multicolumn{8}{|c|}{2018} \\
\hline $\mathbf{T}_{1}$ & 6.70 & 5.94 & 5.76 & 5.66 & 5.63 & 5.21 & 5.82 \\
\hline $\mathbf{T}_{2}$ & 6.70 & 6.25 & 6.02 & 5.89 & 5.50 & 4.88 & 5.87 \\
\hline$T_{3}$ & 6.70 & 6.11 & 6.02 & 5.89 & 5.71 & 5.38 & 5.97 \\
\hline $\mathbf{T}_{4}$ & 6.70 & 6.56 & 6.02 & 6.01 & 5.76 & 5.60 & 6.11 \\
\hline$T_{5}$ & 6.70 & 6.68 & 6.35 & 6.04 & 6.02 & 5.72 & 6.25 \\
\hline$T_{6}$ & 6.70 & 6.64 & 6.27 & 5.94 & 5.85 & 5.73 & 6.19 \\
\hline $\mathbf{T}_{7}$ & 6.70 & 6.40 & 6.04 & 6.02 & 5.94 & 5.12 & 6.04 \\
\hline Mean & 6.70 & 6.37 & 6.07 & 5.92 & 5.77 & 5.38 & \\
\hline L.S.D. 0.05 & (P): 0.21 & (T): & & (PxT): 0.23 & & & \\
\hline \multicolumn{8}{|c|}{$(\mathrm{PX} 1): 0.23$} \\
\hline$T_{1}$ & 6.81 & 5.89 & 5.76 & 5.89 & 5.71 & 5.50 & 5.93 \\
\hline $\mathbf{T}_{2}$ & 6.81 & 6.48 & 6.27 & 6.02 & 5.89 & 5.69 & 6.19 \\
\hline$T_{3}$ & 6.81 & 6.62 & 6.19 & 5.94 & 5.89 & 5.38 & 6.14 \\
\hline $\mathbf{T}_{4}$ & 6.81 & 6.60 & 6.27 & 6.22 & 6.02 & 5.94 & 6.31 \\
\hline$T_{5}$ & 6.81 & 6.80 & 6.40 & 6.35 & 6.19 & 5.89 & 6.41 \\
\hline$T_{6}$ & 6.81 & 6.64 & 6.40 & 6.27 & 6.14 & 5.89 & 6.36 \\
\hline $\mathbf{T}_{7}$ & 6.81 & 6.30 & 6.14 & 6.07 & 6.01 & 5.94 & 6.21 \\
\hline Mean & 6.81 & 6.48 & 6.20 & 6.11 & 5.98 & 5.75 & \\
\hline L.S.D. 0.05 & (P): 0.19 & $(\mathrm{~T}): 0$ & & $(\mathrm{PxT}): 0.24$ & & & \\
\hline
\end{tabular}

Table 10: The effect of some types of packaging on titratable acidity percentage (TA) (as grams of citric acid/100 ml juice) of Balady lime fruits during marketing at room temperature.in 2018 and 2019 seasons.

\begin{tabular}{|c|c|c|c|c|c|c|}
\hline \multirow{2}{*}{$\begin{array}{l}\text { Treatments } \\
\text { (T) }\end{array}$} & \multicolumn{6}{|c|}{ Marketing periods (P) } \\
\hline & 0 days & 2 days & 4 days & 6 days & 8 days & Mean \\
\hline \multicolumn{7}{|c|}{2018} \\
\hline$T_{1}$ & 6.70 & 5.92 & 5.59 & 5.46 & 5.16 & 5.77 \\
\hline $\mathbf{T}_{2}$ & 6.70 & 5.70 & 5.46 & 5.37 & 5.33 & 5.71 \\
\hline $\mathbf{T}_{3}$ & 6.70 & 5.56 & 5.55 & 5.38 & 5.29 & 5.70 \\
\hline $\mathbf{T}_{4}$ & 6.70 & 6.03 & 5.80 & 5.72 & 5.38 & 5.93 \\
\hline$T_{5}$ & 6.70 & 6.01 & 5.93 & 5.67 & 5.38 & 5.94 \\
\hline$T_{6}$ & 6.70 & 6.02 & 5.85 & 5.59 & 5.21 & 5.87 \\
\hline $\mathbf{T}_{7}$ & 6.70 & 5.83 & 5.80 & 5.38 & 5.29 & 5.80 \\
\hline Mean & 6.70 & 5.87 & 5.71 & 5.51 & 5.29 & \\
\hline L.S.D. 0.05 & (P): 0.29 & $(\mathrm{~T}): 0.12$ & & 0.26 & & \\
\hline \multicolumn{7}{|c|}{2019} \\
\hline $\mathbf{T}_{1}$ & 6.81 & 6.40 & 5.53 & 5.37 & 5.24 & 5.87 \\
\hline $\mathbf{T}_{2}$ & 6.81 & 5.84 & 5.76 & 5.68 & 5.50 & 5.92 \\
\hline $\mathbf{T}_{3}$ & 6.81 & 5.73 & 5.63 & 5.50 & 5.37 & 5.81 \\
\hline $\mathbf{T}_{4}$ & 6.81 & 6.19 & 6.14 & 5.63 & 5.50 & 6.05 \\
\hline$T_{5}$ & 6.81 & 6.19 & 6.11 & 6.01 & 5.63 & 6.15 \\
\hline$T_{6}$ & 6.81 & 6.25 & 5.89 & 5.76 & 5.25 & 5.99 \\
\hline $\mathbf{T}_{7}$ & 6.81 & 6.25 & 5.89 & 5.50 & 5.12 & 5.91 \\
\hline Mean & 6.81 & 6.12 & 5.85 & 5.64 & 5.37 & \\
\hline L.S.D. 0.05 & (P):0.26 & (T): 0.12 & (PxT): & & & \\
\hline
\end{tabular}

$\mathbf{T}_{1} \quad$ Perforated plastic bags

$\mathbf{T}_{2} \quad$ Perforated cellophane paper

$\mathbf{T}_{3} \quad$ Perforated plastic boxes

$\mathbf{T}_{4} \quad$ Non-perforated plastic bags
$\mathbf{T}_{5}$ Non-perforated cellophane paper

T6 Non-perforated plastic boxes

$\mathbf{T}_{7}$ Sealed foam plate by polye. stretch 


\subsection{Vitamin $\mathrm{C}$ content in fruit juice}

\subsubsection{During cold marketing}

From Table (11), it is clear that vitamin C content was decreased with the advance of the cold marketing period to minimum values after 5 weeks. Also, data clear that packaging treatments had significant effects on vitamin $\mathrm{C}$ content during cold marketing in both seasons.

Table 11: The effect of some types of packaging on vitamin C content (mg Ascorbic acid/100 $\mathrm{ml} \mathrm{juice)}$ of Balady lime fruits during cold marketing.in 2018 and 2019 seasons.

\begin{tabular}{|c|c|c|c|c|c|c|c|}
\hline \multirow{2}{*}{$\begin{array}{l}\text { Treatments } \\
\text { (T) }\end{array}$} & \multicolumn{7}{|c|}{ Marketing periods (P) } \\
\hline & O week & 1 week & 2 week & 3 week & 4 week & 5 week & Mean \\
\hline & & & 2018 & & & & \\
\hline$T_{1}$ & 45.80 & 42.80 & 38.88 & 38.40 & 38.00 & 36.75 & 40.11 \\
\hline $\mathbf{T}_{2}$ & 45.80 & 44.80 & 44.20 & 39.20 & 37.20 & 37.24 & 41.41 \\
\hline $\mathbf{T}_{3}$ & 45.80 & 43.20 & 42.68 & 40.57 & 39.43 & 39.00 & 41.78 \\
\hline $\mathbf{T}_{4}$ & 45.80 & 44.20 & 44.00 & 41.60 & 40.40 & 39.20 & 42.53 \\
\hline$T_{5}$ & 45.80 & 44.60 & 43.20 & 40.80 & 40.00 & 39.72 & 42.35 \\
\hline $\mathbf{T}_{6}$ & 45.80 & 43.48 & 42.80 & 42.68 & 41.60 & 39.44 & 42.63 \\
\hline $\mathbf{T}_{7}$ & 45.80 & 44.20 & 42.80 & 43.20 & 39.20 & 35.08 & 41.71 \\
\hline Mean & 45.80 & 43.90 & 42.65 & 40.92 & 39.40 & 38.06 & \\
\hline L.S.D. 0.05 & (P):0.86 & (T): 0.2 & & $\mathrm{xT}): 1.0$ & & & \\
\hline & & & 2019 & & & & \\
\hline $\mathbf{T}_{1}$ & 43.30 & 40.40 & 38.00 & 35.70 & 33.60 & 32.87 & 37.31 \\
\hline $\mathbf{T}_{2}$ & 43.30 & 43.03 & 41.16 & 39.90 & 34.30 & 32.20 & 38.98 \\
\hline $\mathbf{T}_{3}$ & 43.30 & 41.60 & 40.00 & 35.70 & 35.00 & 31.35 & 37.83 \\
\hline$T_{4}$ & 43.30 & 42.16 & 41.07 & 40.80 & 38.40 & 36.40 & 40.36 \\
\hline$T_{5}$ & 43.30 & 43.07 & 41.92 & 41.60 & 39.20 & 34.00 & 40.52 \\
\hline$T_{6}$ & 43.30 & 43.23 & 40.80 & 40.00 & 39.44 & 32.61 & 39.90 \\
\hline $\mathbf{T}_{7}$ & 43.30 & 41.87 & 40.70 & 39.20 & 37.00 & 34.13 & 39.37 \\
\hline Mean & 43.30 & 42.19 & 40.52 & 38.99 & 36.71 & 33.37 & \\
\hline L.S.D. 0.05 & (P):1.68 & $(\mathrm{T}):$ & $\begin{array}{ll}27 & \text { (PxT }\end{array}$ & 1.79 & & & \\
\hline
\end{tabular}

$\mathbf{T}_{1} \quad$ Perforated plastic bags

$\mathbf{T}_{2} \quad$ Perforated cellophane paper

$\mathbf{T}_{3} \quad$ Perforated plastic boxes

$\mathbf{T}_{4} \quad$ Non-perforated plastic bags
$\mathbf{T}_{5} \quad$ Non-perforated cellophane paper

$\mathbf{T}_{6} \quad$ Non-perforated plastic boxes

$\mathbf{T}_{7} \quad$ Sealed foam plate by polye. stretch

The least values $(40.11$ and $37.31 \mathrm{mg} / 100 \mathrm{~g})$ of vitamin $\mathrm{C}$ content were recorded in fruits packed in Perforated plastic bags (T1) treatment in the two seasons, respectively). The Highest values (42.63 and $42.53 \mathrm{mg} / 100 \mathrm{~g}$ ) of vitamin C content were recorded in fruits packed in non-perforated plastic boxes (T6) treatment and non-perforated plastic bags (T4) treatment without significant differences in the first season. For the second season The Highest values $(40.52$ and $40.36 \mathrm{mg} / 100 \mathrm{~g}$ ) of vitamin C content were recorded in fruits packed in Non-perforated cellophane paper (T5) treatment and non-perforated plastic bags (T4) treatment without significant differences.

The interaction between the cold marketing period and packaging treatments had significant effects on vitamin $\mathrm{C}$ content during cold marketing in the two seasons.

\subsubsection{During marketing at room temperature}

Vitamin $C$ content was gradually decreased with advancing marketing at room temperature period in both seasons as illustrated in the table (12). Packaging treatments had significant effects on vitamin $\mathrm{C}$ content and the lowest values came from perforated cellophane paper (T2) during both seasons.

The interaction between the marketing period and packaging treatments had significant effects on vitamin $\mathrm{C}$ content during marketing at room temperature in the two seasons. The least values $(28.50$ and $27.23 \mathrm{mg} / 100 \mathrm{~g}$ ) of vitamin $\mathrm{C}$ content resulted after 8 days during marketing at room temperature with perforated cellophane paper (T2) treatment in the two seasons, respectively. 
Table 12: The effect of some types of packaging on vitamin C content (mg Ascorbic acid/100 ml juice) of Balady lime fruits during marketing at room temperature in 2018 and 2019 seasons.

\begin{tabular}{|c|c|c|c|c|c|c|}
\hline \multirow{2}{*}{$\begin{array}{l}\text { Treatments } \\
\text { (T) }\end{array}$} & \multicolumn{6}{|c|}{ Marketing periods (P) } \\
\hline & 0 days & 2 days & 4 days & 6 days & 8 days & Mean \\
\hline \multicolumn{7}{|c|}{2018} \\
\hline$T_{1}$ & 45.80 & 40.00 & 38.00 & 34.00 & 30.40 & 37.64 \\
\hline $\mathbf{T}_{2}$ & 45.80 & 37.33 & 36.00 & 34.40 & 28.50 & 36.41 \\
\hline $\mathbf{T}_{3}$ & 45.80 & 41.33 & 34.20 & 34.00 & 32.40 & 37.55 \\
\hline $\mathbf{T}_{4}$ & 45.80 & 40.33 & 40.00 & 38.00 & 34.00 & 39.63 \\
\hline$T_{5}$ & 45.80 & 40.55 & 38.00 & 37.60 & 32.40 & 38.87 \\
\hline$T_{6}$ & 45.80 & 41.00 & 38.67 & 36.80 & 32.00 & 38.85 \\
\hline $\mathbf{T}_{7}$ & 45.80 & 43.00 & 40.40 & 38.00 & 32.00 & 39.84 \\
\hline Mean & 45.80 & 40.51 & 37.90 & 36.11 & 31.67 & \\
\hline L.S.D. 0.05 & & (P): 0.99 & & & (PxT): 1.15 & \\
\hline \multicolumn{7}{|c|}{2019} \\
\hline$T_{1}$ & 43.30 & 37.00 & 36.60 & 33.27 & 29.13 & 35.86 \\
\hline $\mathbf{T}_{\mathbf{2}}$ & 43.30 & 34.00 & 32.00 & 31.87 & 27.23 & 33.68 \\
\hline $\mathbf{T}_{3}$ & 43.30 & 38.00 & 32.00 & 31.03 & 29.20 & 34.71 \\
\hline $\mathbf{T}_{4}$ & 43.30 & 40.00 & 36.53 & 33.47 & 30.40 & 36.74 \\
\hline $\mathbf{T}_{5}$ & 43.30 & 41.00 & 36.20 & 32.60 & 29.67 & 36.55 \\
\hline$T_{6}$ & 43.30 & 42.00 & 35.60 & 32.93 & 28.67 & 36.50 \\
\hline $\mathbf{T}_{7}$ & 43.30 & 41.00 & 34.47 & 32.67 & 31.33 & 36.55 \\
\hline Mean & 43.30 & 39.00 & 34.77 & 32.55 & 29.38 & \\
\hline L.S.D. 0.05 & & $(\mathrm{P}): 1$. & $(\mathrm{T}): 0$ & & T):2.11 & \\
\hline
\end{tabular}

$\mathbf{T}_{1} \quad$ Perforated plastic bags

$\mathbf{T}_{2} \quad$ Perforated cellophane paper

$\mathbf{T}_{3} \quad$ Perforated plastic boxes

$\mathbf{T}_{4} \quad$ Non-perforated plastic bags
T$_{5}$ Non-perforated cellophane paper

T6 Non-perforated plastic boxes

$\mathbf{T}_{7}$ Sealed foam plate by polye. stretch

\section{Discussion}

In citrus fruits, post-harvest handling losses are estimated at 5-10 percent in most developed countries, whereas in developing countries they are over 25-30 percent (Coursey and Booth, 1971). Nowadays, the usage of different packaging types for fresh fruit marketing widely a common practice that helps in extending marketability by reducing shrinkage, weight loss, and occurrence of various blemishes. Some packaging types used are partially permeable to gases and water vapour and can also be intended to modify fruit's micro atmospheric condition and hence, delayed the deterioration at room temperature. Water loss can also be one of the major causes for deterioration, since it not only results in indirect quantities losses but also results losses in appearance (due to wilting and shriveling) and nutritional quality.

The decreasing fruit weight loss due to packaging might be due to its induce a modification of microclimatic of fruits, where reducing the evaporation and respiration processes. The packaging does not directly influence the rate of water loss, but the need for a gas tight environment for packaging during storage and transport often results in significantly higher relative humidity around the commodity and consequently reduces water loss compared to air storage (Kader, 1986).

The obtained results indicated that packaging significantly reduced the fruit weight loss and decay percentage. The present results confirmed the earlier finding of Li et al. (2011), Tabatabarkoloor (2012); El-Sheikh et al. (2014); Mansour (2015); Bhattarai and Shah (2017). They concluded from their studies that using wrapping and packaging was effective in decreasing the fruit weight loss and decay percentages during the storage. On other hand, Rygg and Wells (1962) reported that plastic film may promote an unmarketable $\%$ of fruit lemons because of high levels of humidity and $\mathrm{CO} 2$ within the sealed package.

Packaging of fruits significantly increased fruit juice percentage (Zagzog et al., 2012; Mansour, 2015). However, Obenland et al. (2008) and Cohen et al. (1990) recorded that juice \% was insignificantly affected by the tested packaging treatments.

The reduction in juice content may be due to losing moisture content. The packaging caused a significant reduction in total soluble solids percentage (TSS\%) (Li et al., 2011; Zagzog et al., 2012; 
Rupinder Singh, 2017). In contrast, total soluble solids percentage (TSS\%) was increased with packaging treatments (Ji Hua et al., 2011). While, it was insignificantly affected by the tested packaging treatments as compared with un-packaging in acid lime fruits (Ramin and Khoshbakhat, 2008).

Maximum TSS in fruit was recorded at the end of storage. Such finding may be due to maximum water loss in these fruits. Packaging reduces respiration rates and may, therefore delay the utilization of organic acids (Jawandha et al., 2012). In addition, the retention of higher value for TSS might be due to lowering of water loss by transpiration during the storage period (Hussein et al., 1998). Also, higher TSS values in fruits may be due to retarding the respiration rate, water losses, and conversions of polysaccharides into disaccharides and monosaccharides (Munoz et al., 2006).

The packaging treatments were an insignificant effect on acidity (Obenland, et al., 2008; Ramin and Khoshbakhat, 2008; Sanches et al., 2011). While Mohsen (2011) and Li et al. (2011) found that packaging treatments decreased acidity percentage. But, Tefera et al. (2007) and Ji Hua et al. (2011) recorded increases in acidity percentage by packaging applications.

The decrease of acid percentage during the marketing period could be due to the destruction of organic acids through oxidation and consumption of these acids, as an organic substrate in the respiration processes of the fruit tissues. The progress of the marketing period was found to raise the respiration rate of the fresh fruits (Hussien et al., 1998).

The total soluble solids were increased gradually as prolong the marketing period. This increment could be due to the solubilization of compounds other than carbohydrates to sugars or some extent concentration effects. Hydrolysis of cell wall constituents could also possibly contribute to the increase in Brix (Burn, 1990).

The ascorbic acid content in fruits is known to be decreased during storage possibly due to utilization of organic acids during respiration or their conversion to sugars (Kader, 2002).

In addition, the loss in ascorbic acid content during storage might be attributed to the rapid conversion of L-ascorbic acid into dehydroascorbic acid in the presence of L-ascorbic acid oxidase (Hussien et al., 1998). In addition, the ascorbic acid content in citrus fruits generally declines with enhanced storability due to an increase in the activity of oxidizing enzymes like ascorbic acid oxidase, peroxidase, and catalase which might have into dehydroascorbic acid as reported by Mapson (1970), Ladaniya and Shyam Singh (1998).

The packaging treatments were an insignificant effect on Ascorbic acid content (Li et al., 2011; Zagzog et al., 2012), which reported that ascorbic acid content was decreased with packaging treatments. But, it is retained with packaging treatments (Tefera et al., 2007; Ramin and Khoshbakhat, 2008).

\section{Conclusion}

From the previous results; it can be recommended to pack the fruits in sealed bags with calcium hydroxide. This packaging leads to prolonging the marketing period from one to five weeks under normal or cooling conditions, respectively. In addition, preserving the fruit quality.

\section{References}

A.O.A.C., 1985. Official Method Analysis. Association of Official Analytical Chemists, Washington, DC., USA.

Al-Hiti, S.M.J., 2005. Citrus reticulate influence of packages types and storage temperatures on mandarin fruits storability (Citrus reticulata) local cultivar. AL-Anbar Journal of Agricultural Sciences, 2(3): 67-74.

Analytical software, 2005. Statistix 8.1 for Windows analytical software. Tallahassee, Florida

Bhattarai, B.P. and R. Shah, 2017. Effect of Different Packaging Materials on Post-Harvest Status of Mandarin (Citrus reticuleta B.). J. Hortic., 4: 4

Burn, J.K., 1990. $\alpha$ and $\beta$ galactosidase activity in juice of Valencia orange. Phytochemistry, 29: 24252429.

Chaudhary, P.R., G.K. Jayaprakasha, R. Porat, and B.S. Patil, 2015. Influence of modified atmosphere packaging on "star ruby" grapefruit phytochemicals. Journal of agricultural and food chemistry, 63(3): 1020-1028. 
Cohen, E., Y. Shalom, and I. Rosenburger, 1990. Postharvest ethanol buildup and off-flavor in 'Murcott' tangerine fruits. Journal of Amer. Soc. Hort. Science, 115: 775-778.

Coursey, D.G., and R.H. Booth, 1971. Post-harvest loses in perishable tropical produce. Proc.6th Br. Insect. Fung. Conf., 3: 673.1

D’Aquino, S., M.G. Molinu, A. Piga, and M. Agabbio, 2001. Influence of film wrapping on quality maintenance of "Salustiana" oranges under shelf life conditions. Italian Journal of Food Science, 1(13): 87-100.

Dhillon, W.S., B.V.C. Mahajan, T.S. Chahal, M. Kumar, M.K. Sidhu, and S.P. Singh, 2016. Effect of different packaging films on shelf-life and quality of Daisy mandarin under ambient conditions. The Horticultural Society of India (Regd.), 73(2): 262-266.

El-Sheikh, M.H., M.M.M. Abd El-Migeed, and M.M.S. Saleh, 2014. Effect of Some Bagging Types under Different Conditions of Cold Temperature on Storability of Lime Fruits. World Applied Sciences Journal 30 (4): 395-401.

Faasema, J., J.O Abu, and J.S. Alakali, 2011. Effect of packaging and storage condition on the quality of sweet orange (Citrus cinesis). Journal of Agricultural Technology, 7(3): 797-804.

Hussain, I., M. Asif, M. Ahmad, M. Khan, and I. Shakir, 2004. Effect of Un-packaging on the postharvest behavior of citrus fruits in NWFP. Pak. J. Nutr., 3 (6): 336-339.

Hussein, A.M., M.B. El-Sabrout, and A.E. Zaghloul, 1998. Postharvest physical and biochemical changes of common and late types of seedy guava fruits during storage. Alex. J. Agric. Res., 43(3): 187-204.

Jawandha, S.K., P.S. Tiwana, and J.S. Randhawa, 2012. Effect of low density polyethylene packaging and chemicals on ambient storage of kinnow. Asian Journal of Food and Agro-Industry J. Food Ag-Ind., 5(02): 112-118.

Ji H., Guan JunFeng., Feng YunXiao., Li LiMei and Sun YuLong, 2011. Effect of MA package and prestorage on quality and browning of Black Diamond plums during cold storage. J. Fruit Science, 28(1): 147-150.

Kader, A.A., 1986. Biochemical and physiological basis for effects of controlled and modified atmosphere on fruits and vegetables. Food Tech., (May): 99-102.

Kader, A.A., 2002. Recommendations for maintaining postharvest quality. Post harvest Technology Research Information Center. Dept of Pomology. Univ. of California. One Shield Ave., Davis, CA., 95616-8683.

Kawade, X., and L.G. Albrigo, 1979. Effects of film packaging, in- carton air filters and storage temperatures on the keeping quality of Florida grapefruit. Proc. Fla. State Hort. Soc., 92: 209212.

Ladaniya, M.S., and Sh. Singh, 1998. Post harvest technology of Nagpur mandarin (Citrus reticulata Blanco). NRCC, Nagpur, Technical Bulletin-2: 44.

Li, X.L., J.Q. Li, Z.Y. Yang, and Q.F. Yuan, 2011. Effect of paper bagging on quality and appearance of Newhall navel orange fruits. Chinese Journal of Southern Agriculture, 42 (7): 771-773.

Mansour, A.H.A., 2015. Effect of pre and postharvest treatments on fruit characteristics of Balady mandarin (Citrus reticulata L.) during storage Ph.D. Thesis Fac. of Agric. Assiut Univ. Egypt.

Mapson, C.W., 1970. Vitamins in fruits. In: Biochemistry of fruits ad their products. Vol 1. Hulme AC (ed.) Academic Press, New York.

Ministry of Agriculture and Land Reclamation Statistics, 2015. Annual Reports and Agricultural Economic Research in A.R.E.

Mohammed, M., and L.D. Wickham, 2011. Quality changes in balata (Manilkara bidentata) fruit as affected by modified atmosphere packaging during refrigerated storage. Acta Horticulturae, 906: 63-66.

Mohsen, A.T., 2011. Performance of peach and apricot fruits at cold storage and shelf life as affected by modified atmosphere packaging. American-Eurasian Journal of Agricultural \& Environmental Sciences, 10(5): 718727.

Munoz, P.H., E. Almenar, M. Ocio, and R. Gavara, 2006. Effect of calcium dips and chitosan coating on post harvest life of strawberries (Fragaria ananassa). J. Postharvest Biol. Tec., 39:247-253.

Obenland, D., S. Collin, J. Sievert, K. Fjeld, J. Doctor, and M. Lu Arpaia, 2008. Commercial packing and storage of navel oranges alters aroma volatiles and reduces flavor quality. Postharvest Biol. and Tech., 47: 159-167. 
Panhwar, F., 2006. Post Harvest Technology of Fruits and Vegetables. http://www.eco-web. Com

Ramin, A.A., and D. Khoshbakhat, 2008. Effects of Microperforated Polyethylene Bags and Temperatures on the Storage Quality of Acid Lime Fruits. American-Eurasian J. Agric. \& Environ. Sci., 3 (4): 590-594.

Reddy, B.V., G. Bindu Madhavi, D. Venkata Reddy, V. Chenga Reddy, and B. Srinu, 2008. Effect of different packing materials on the shelf life and quality of acid lime (Citrus aurantifolla Swingla) at room temperature. J. Dairying, Foods, H.S., 27(3/4): 216-220.

Rygg G.L., and A.W. Wells, 1962. Experimental storage of California lemons in controlled atmosphere. U. S. Department Agriculture Market Serve. AMS-475, $11 \mathrm{p}$.

Sanches, J., P. Cia, S.R. de T. Valentini, E. Benato, E.A. Chagas, and R. Pio, 2011. Modified atmosphere and refrigeration for the postharvest conservation of 'Fukuhara' loquat. Portuguese, Bragantia, 70 (2): 455-459.

Shaarawi, A.M.A., Z.A. Zaki, A.S.A. Abd- Allah, and M.E.A. Abo Rehab, 2014. Effect of Some Biological Control Agents and Packaging Types on Storability of Lime Fruits. Middle East Journal of Agriculture Research, 3(4): 1057-1064

Singh, R., S. Senthilkumar, and S.K. Singh, 2018. Role of Packaging on Shelf Life and Quality of Kinnow Journal of Pure and Applied Microbiology, 12(2): 725-731

Snedecor, G.W., and W.G. Cochran, 1990. Statistical Methods 7th Edn, Iowa State University Press, Ames, IA, USA

Sohi, H.S., P.S. Aulakh, J. Singh, and S. Ahmed, 2016. Effect of different packaging materials on the storage life and quality of kinnow Res. Environ. Life Sci. 9(9): 1072-1075.

Tabatabaekoloor, R., 2012. Orange responses to storage conditions and polyethylene wrapped liner. Agric Eng Int: CIGR Journal, 14 (2):127-130.

Tefera, A., T. Seyoum, and K. Woldetsadik, 2007. Effect of disinfection, packaging, and storage environment on the shelf life of mango. Biosystems Engineering, 96 (2): 201-212.

Viskelis, P., M. Rubinskiene, A. Sasnauskas, C. Bobinas, and N. Kvikliene, 2011. Changes in apple fruit quality during modified atmosphere storage. Journal of Fruit and Ornamental Plant Research, 19(1): 155-165.

Zagzog, O.A.I., S.M. El-Hefnawi, and F.M.S. Mohsen, 2012. Effect of some packaging treatments on balady Lime fruit under cold storage conditions. J. Product. \& Dev., 17(1):1 - 23. 